\title{
Form over Substance: Possibilities to Prove Electoral Irregularities under Serbian Law
}

\author{
Jelena Jerinić \\ Union University School of Law (Belgrade), Serbia \\ jelena.jerinic@pravnifakultet.rs \\ https://orcid.org/0000-0002-3216-3635
}

Received: 24. 10. 2020

Accepted: 27.11.2020

\section{ABSTRACT}

The article analyses Serbian legislation and case law applicable to electoral disputes, in particular those relevant to the determination of facts in these disputes, and the potential influence of procedural rules on the efficiency of protection of constitutionally guaranteed electoral rights. Besides Serbian legislation and case law, the analysis leans on the relevant European standards, including the case law of the European Court of Human Rights. The results show that in practice, electoral commissions and courts use a limited circle of means of evidence and that the evidence submitted by complainants is not evaluated in the same way as the one coming from electoral boards. Although the application of general rules on administrative disputes is explicitly envisaged in electoral laws, the Administrative Court usually defers to the decisions and reasoning of electoral commissions, without supplementing the facts within court procedure, and relatively rarely or selectively decides in full jurisdiction. The author suggests amendments to the relevant legislation, aiming at a more explicit inclination towards the relevant procedural norms or, possibly, special regulation of evidencing in electoral legislation. In her view, a more explicit direction towards the application of the rules of general administrative procedure, in particular rules on evidencing, would lead to their more consistent application in practice.

Keywords: Administrative Court, administrative procedure, elections, electoral rights, evidence, Serbia 


\section{Introduction}

In the beginning of July 2020, amidst the COVID-19 pandemic, the Serbian Administrative Court passed a number of identical judgements, annulling identical decisions of the Republic Electoral Commission (REC), finding shortcomings in their rationale, i.e. the way facts have been determined in the procedure of electoral rights protection before the REC (Danas, 2020). These decisions motivated the author to contemplate the deficiencies of current Serbian legislation governing electoral rights protection - in particular, determination of facts in these procedures.

Serbian Constitution guarantees electoral rights and their legal protection (Serbian Constitution 2006, A. 52, para. 3). More detailed regulation is in electoral laws, envisaging a two-instance protection - before the relevant electoral commission followed by an appeal procedure before the Administrative Court. This is a frequent combination in countries of Central and Eastern Europe (Nastić, 2016, p. 167) and some other European jurisdictions, while in some this is achieved before Parliament, a special parliamentary body or the constitutional court (Venice Commission CDL-EL(2019)001, pp. 9-12). Protection by at least one judicial instance is considered a European standard, recommended by the Code of Good Practice in Electoral Matters (Venice Commission, CDL-AD (2002)23; Fasone, 2017, p. 253).

It should also be noted that Serbian electoral administration is not fully professionalized, since electoral commissions they are appointed upon proposal of political parties (or candidate lists). They have permanent and extended compositions, in which they decide during the electoral process and which are usually quite numerous. ${ }^{1}$ This solution was criticised in view of the level of independence, autonomy and professionality of these bodies, as well as the questionable legal status of REC (CRTA, 2018b), and the same is applicable to local electoral commissions.

With proportional elections and a single electoral unit (in elections on all levels of government) and no hierarchical relation between electoral commissions established under separate electoral laws (central, provincial and local), there is no control by a higher instance electoral commission, as in some other European countries (Venice Commission, CDL-AD, (2006)013).

The Constitutional Court has residual competence in electoral disputes (A. 167, рага. 2, item 5 of the Constitution; see Vučetić, 2015a, pp. 156-157; Nastić, 2014, pp. 66-74), but that remains in the domain of theory, since all electoral laws envisage the competence of the Administrative Court in electoral disputes (Stojanović, 2012, p. 37) - from presidential elections ${ }^{2}$ to elec-

1 According to A. 33 LEMP, permanent composition of REC consists of the president and 16 members, appointed by the Parliament, while its extended composition also includes one representative of each confirmed party list (in 2020 elections there were 21 lists). In 2018 Belgrade elections, the Belgrade Electoral Commission (BEC) had 12 permanent members, while 20 of the 24 candidate lists had their members in the extended composition (CRTA, 2018a, 9).

2 E.g. Conclusion of the Constitutional Court (CC), VIU-101/2017 of 13 July 2017, where the Constitutional Court declared itself incompetent to decide on the request of a presidential 
tions for local neighbourhood districts (mesne zajednice). ${ }^{3}$ The Constitutional Court remains competent to decide on constitutional complaints, as a remedy of last resort, if proven that acts of state bodies violated constitutionally guaranteed electoral rights (Stojanović, 2012, pp. 45-48) and for review of constitutionality and legality of general legal acts in relation to elections (Nastić, 2016, pp. 174-175).

The present system of electoral rights protection is set up by the Law on Election of Members of Parliament (LEMP, A. 93-97), ${ }^{4}$ while other electoral laws lean on it, envisaging its analogous application in many aspects. This is the case with the Law on Local Elections (LLE, A. 58) ${ }^{5}$ and the Law on Election of the President of the Republic (A. 8), ${ }^{6}$ while the relevant provincial regulation essentially does the same, but in a less favourable manner in terms of its nomotechnique - by almost literally taking over the provisions of LEMP. ${ }^{7}$

Legal protection of electoral rights has been a current topic in Serbia since the re-introduction of multiparty elections at the end of the 20th century (Bieber 2003; Thompson and Kuntz 2004). Electoral disputes are always a striking feature of the electoral process and Serbian authors have expressed serious criticism towards the existing legal mechanisms to that end (Pajvančić, 2001; Nastić, 2014).

The right to legal protection belongs to every voter, candidate or nominator of electoral list (LEMP, A. 94). The author purports that standing should be understood widely, as to include the application of rules of general administrative procedure allowing the so-called representatives of collective interest and wider interests of the public to gain standing in procedures in which the outcome could influence the interests they represent (LGAP, A. 44, para. 3). This would be in accordance with comparative European practice (Venice Commission CDL-EL, (2019)001, pp. 17-18). However, application of these provisions in administrative procedure is not yet widely accepted and they have not yet been applied in electoral disputes. Moreover, earlier decisions of electoral commissions show that they take standing narrowly, allowing it only to persons explicitly listed in LEMP. ${ }^{8}$

The rules distinguish two types of complaints - against decisions of the electoral commission and for irregularities in the conduct of electoral activities (Vučetić, 2015a, pp. 140-141). Deadlines are short and competent bodies tied

candidate, since protection in these cases is provided before the Administrative Court.

3 Legal position of the Civil Law Section of the Supreme Court of Cassation adopted on 18 November 2014 (in Serbian only).

4 Zakon o izboru narodnih poslanika (Serbian only), Official Gazette No. 35/00 with amendments.

5 Zakon o lokalnim izborima (Serbian only), OG 129/07 with amendments.

6 Zakon o izboru predsednika Republike (Serbian only), OG 111/07 with amendments.

7 A. 54-58 Pokrajinska skupštinska odluka o izboru poslanika u Skupštinu Autonomne pokrajine Vojvodine (Serbian only), OG of AP Vojvodina 23/2014 with amendments.

8 For instance, during 2018 Belgrade elections, BEC dismissed 15 complaints of monitors of the organisation CRTA for absence of standing. See f.n. 25. 
by demands of urgent proceedings, all in the aim of efficient termination of the electoral process.

During presidential and parliamentary elections (as well as local elections in Belgrade) usually several hundreds of complaints are submitted to the electoral commission, and a few hundred get their epilogue before the court. ${ }^{9}$ Analysis of these proceedings is hampered by the fact that electoral commissions usually do not publish summary reports of received and decided complaints, ${ }^{10}$ and the data in annual reports of the Administrative Court are given in aggregate, for all elections conducted in a given year (see e.g. Upravni sud, 2019, pp. 9-10).

This and earlier analysis show that every election is usually marked by a larger number of irregularities of a certain type: e.g. falsified signatures during the nomination process and the so-called "Bulgarian trains" or "carousel voting" in 2016 (Nastić, 2016); parallel voter registers (particularly evident from 2018 Belgrade elections; also see Pavlović, 2020, p. 26); an unusually big number of requests for insight into voter materials claiming irregularities in vote counting, which marked the June 2020 parliamentary elections. The last elections, held just after state of emergency proclaimed due to the COVID-19 pandemic was lifted, according to reports of foreign and domestic monitoring missions, was marked by almost twice as many irregularities in comparison to previous cycles (Cvejin, 2020).

Against the presented background, the author poses three main research questions. What are the relevant procedural rules, which electoral commissions employ to determine the facts of individual cases? What means of evidence are predominantly used by the commissions and the Administrative Court? What are the characteristics of the review carried out by the Administrative Court? The author's hypothesis is that these bodies do not make full use of available rules of general administrative procedure, thus hampering the procedural position of complainants and, bearing in mind the established European standards, possibly influencing the very effectiveness of available legal remedies.

9 E.g. according to some sources, during 2012 parliamentary elections, there were 633 appeals to the Administrative Court, while only 29 in 2014 (Vučetić, 2014, p. 1279). According to BEC, during 2018 Belgrade elections, there was a total of 197 complaints and 119 appeals to the Administrative Court. Other organisations reported that, only after the election day, there were 205 complaints and 94 appeals (CRTA 2018a, 24). The author had access to 190 complaints (out of which 3 were adopted, 18 dismissed and 169 rejected). Decisions of the Administrative Court were accessed from the web presentation of the Administrative Court (http:// www.up.sud.rs/latinica/izborni-predmeti).

REC published all its rulings on complaints during 2020 parliamentary elections (https://www. rik.parlament.gov.rs/tekst/sr/2171/resenja-po-prigovorima.php). There were several thousands of complaints and a large portion related to fears for security during the COVID-19 pandemic and a very large number of complaints related to irregularities on the election day. Most were rejected.

10 Commissions usually publish only reports on final results of the elections, not containing detailed information on how the elections were conducted, nor on submitted complaints and appeals. International organisations stress the importance of databases on electoral disputes (Petit, 2000, pp. 17-19). 


\section{Methods}

The author uses the method of legal analysis, i.e. normative analysis of legal norms and content analysis of selected case law of electoral commissions and the Administrative Court. The research is focused on Serbia, but the case law is analysed both in view of current Serbian legislation and the established European standards, as seen by international election observation organisations and the of the European Court of Human Rights (ECHHR). Similar analysis for other countries can be found in academic literature (e.g. for Russia see Popova, 2006).

The analysis covers case law concerning 2020 parliamentary elections, as well as a number of rulings of the electoral commission and the Administrative Court passed during 2018 elections for councillors of the Belgrade City Assembly, ${ }^{11}$ while case law concerning earlier elections has been selected based on its subject matter, i.e. the influence of evidencing rules in determination of facts in electoral matters. Belgrade was chosen for its sizable electorate, making up more than $20 \%$ of the total number of voters in Serbia.

Issues around electoral governance in Serbia have been subject of research in fields other than law. Academic research is primarily in the field of political science (e.g. in relation to elections as an institution of the hybrid political regime, including the role of REC, see Pavlović, 2020; or on comparison of scale of electoral manipulations in the 2010s and during the authoritarian regime of the 1990s, see Castaldo, 2020), while organisational aspects are thoroughly analysed by national and international election observation organisations (e.g. OSCE/ODIHR or the local organisation CRTA). The author takes due notice of that and recognises that these aspects are as relevant to the wider theme of good electoral governance, but maintains a strict focus on legal rules and their influence on providing effective protection of electoral rights.

\section{Results}

\subsection{Application of procedural rules by analogy}

The LEMP only partly regulates the procedure for protection of electoral rights, directing towards analogous application of the Law on Administrative Disputes $(L A D)^{12}$ in the procedure before the Administrative Court. However, it does not envisage application of other procedural laws in the procedure before the competent electoral commission. Even though the LEMP has been amended several times, this legal gap was not filled. ${ }^{13}$ Nevertheless, the rules of general administrative procedure are applied by electoral commissions and

11 Thanks to kindness of the president of BEC and the Belgrade city administration, the author gained insight into all complaints submitted to BEC during the 2018 elections for local councillors, as well as BEC's decisions on these complaints.

12 Zakon o upravnim sporovima (Serbian only), OG 111/09.

13 E.g. 2004 and 2011 amendments related to determination of competence of the court to decide on appeals (first by the Supreme Court and later by the Administrative Court), but not to analogous application of procedural rules in the procedure before the commission. 
the gap left by the LEMP has been filled by their rules of procedure ${ }^{14}$ and this has been accepted in the Court's case law.

There is no doubt in Serbian theory nor case law that the application of the Law on General Administrative Procedure (LGAP) $)^{15}$ in electoral matters is both natural and logical. Some authors go so far to equate the work of electoral commissions with single case decision-making in administrative matters (Milenković, 2012, pp. 201-202), albeit there is no real need for that. Elections are a sui generis legal matter ant their similarity to classical administrative matters is enough for LGAP's analogous application.

Application of adequate procedural rules is necessary to secure effective legal protection of electoral rights. Their inconsistent application leaves the constitutionally guaranteed protection on the level of a proclamation without seriously affecting the electoral process and enjoyment of electoral rights by each individual voter. Therefore, in ECtHR case law protection of the right to free elections of A. 3 of Protocol 1 to the European Convention for the Protection of Human Rights and Fundamental Freedoms (ECHR) is complemented by the guarantee of A. 13 on the right to an effective remedy (ECHHR. 2019, pp. 24-26; Popović, 2017; Beširević et al., 2017, pp. 173-206). According to the ECtHR, the procedure for electoral right protection should guarantee a fair, objective and reasoned decision and be able to prevent any form of abuse of power. ${ }^{16}$ The reasoning of the Serbian Administrative Court in its July 2020 decisions mentioned at the beginning of this text is in line with that position.

In order to determine which provisions of LGAP and LAD can (or rather, should be) applied in electoral disputes, the notion of analogous application should be clear. Application by analogy, or application by similarity, is a common method of filling legal gaps (Lukić, 1994, pp. 323-327; Vasić et. al., 2019, pp. 368-371; Spasojević, 1991). This does not mean that to a certain legal situation (in this case legal protection of electoral rights) a specific law should be applied in full, but to the extent in which there is similarity, or to the extent that law is appropriate to the aim and legal nature of the concrete legal situation. It cannot be said in advance what is the measure or volume of that similarity - and, consequently, application - because analogous application demands a certain level of interpretation, where administrative or court case law play a key role. Some provisions cannot be applied at all, as they do not

14 E.g. A. 24 Rules of Procedure of the Republic Electoral Commission (Poslovnik Republičke izborne komisije - Serbian only), OG 16/20 with amendments; A. 22 Rules of Procedure of the Belgrade Electoral Commission (Poslovnik Gradske izborne komisije - Serbian only), OG of the City of Belgrade 37/18 with amendments; A. 22 KEC Rules of Procedure of the Kragujevac Electoral Commission (Poslovnik Gradske izborne komisije grada Kragujevca - Serbian only), OG of the City of Kragujevac 8/08. The same was envisaged in earlier REC rules (e.g. A. 22 of the 2000 rules and A. 22 of the 2002 rules). On the other hand, such a provision is not contained in the rules of procedure of the Provincial Electoral Commission (Poslovnik Pokrajinske izborne komisije - Serbian only), OG of the Autonomous Province of Vojvodina 11/20.

15 Zakon o opštem upravnom postupku (Serbian only), OG 18/16 with amendments.

16 It should be noted that ECtHR caselaw directly applies only to parliamentary elections. In Serbian circumstances, where LEMP applies by analogy to all other elections, ECtHR standards can be considered for those elections, as well. 
suit the legal nature of the matter, while others cannot be applied literally, but in an adapted way. This is an established position in Serbian administrative practice (Pljakić, 2016, p. 247).

In Serbian law, numerous procedures are implemented according to the rules of LGAP. Their volume is measured in hundreds ${ }^{17}$ and two types can be distinguished among them. The first being special administrative procedures (Lončar, 2017), when there is no doubt as to LGAP's application to them - it is applied as a subsidiary law ${ }^{18}$ lex specialis, whenever a specific law does not envisage differently. ${ }^{19}$ Such derogation from general administrative procedure can be envisaged only by law, and never by an act of lesser legal force (Tomić, 2017, p. 106; Cucić 2011, p. 64). Other procedures, such as electoral disputes, demand application by analogy and are thus not special administrative procedures (that is, by their legal nature they are not administrative procedures at all). These are sometimes labelled as sui generis procedures (Dimitrijević, 2014, pp. 149-150). LGAP itself does not mention, nor regulate, rules for its own analogous application, but it is customarily prescribed by laws, and not by bylaws.

As said, analogous application of LGAP in complaint procedures before electoral commissions is not envisaged by law, ${ }^{20}$ but by rules of procedure of electoral commissions. This solution can be criticized by three types of arguments. The first reside in the area of nomotechnique and are particularly obvious in the case of local elections, where analogous application of LGAP is reached in the "second step" - via rules of procedure of the republic electoral commission. ${ }^{21}$ Such nomotechnical gymnastics seem quite unnecessary when there is a simpler and more elegant solution - referral to analogous application of LGAP in the electoral law itself.

Besides reasons of good legal technique, such a solution is not in line with the demand of legal certainty and the need to inform voters on possibilities for legal remedies. It is an established European standard that complainants should be aware, i.e. that the law should clearly point towards the type and number of evidence to be submitted in support of suspicions of electoral irregularities. Moreover, the law is to clearly state the basis for partial or full annulment of elections. Absence of clear and unambiguous standards con-

17 The list of laws regulating special administrative procedures compiled by the line ministry for purposes of their harmonisation with LGAP contains 265 laws, in 12 areas. Each of these laws regulates at least one procedure to which LGAP applies as subsidiary law (MDULS 2017).

18 There are also opinions that subsidiarity is not obligatory nor exclusive (e.g. Lilić, 2019).

19 However, even a special law cannot deviate from general principles of LGAP (see it's A. 3 para. 2).

20 Except in the case of the Law on National Councils of National Minorities (Zakon o nacionalnim savetima nacionalnih manjina - in Serbian only), OG 72/09 with amendments. This law, besides application of LEMP, envisaged the application of LAD, but also of LGAP (A. 43, para. 2) and not its analogous, but direct application.

21 LLE (A. 15, para. 2) envisages that the [local] electoral commission analogously applies instructions and other acts of the REC relating to conducting elections for members of Parliament, hence according to the established position of the Administrative Court, it is taken that this also includes its rules of procedure which, in its turn, envisages analogous application of LGAP (e.g. Judgement AC, III-1 Už. 55/20, 10 June 2020).

Therefore, one law refers to analogous application of a bylaw that refers to analogous application of another law! 
cerning evidence could endanger the whole electoral process and render the protection of electoral rights meaningless (on OSCE standards in that respect see Petit, 2000, pp. 11-13).

The third group of arguments concerns the typology and hierarchy of legal acts. Rules of procedure are general legal acts of internal nature which usually regulate issues of significance for work and decision-making of collective bodies. Thus LEMP in A. 34 para. 2. empowers the REC to pass rules of procedure for its work [emphasis added] and not to regulate other issues. It is not customary even for bylaws of state bodies (e.g. state administration bodies, such as ministries) to determine analogous application of laws, let alone rules of procedure of electoral commissions.

Rules of procedure are susceptible to more frequent changes than laws and, even though it is hard to imagine that this provision would be omitted from the REC rules, that is not impossible, and thus carries a certain potential for legal uncertainty. Potential discrepancies between rules of procedure of over 150 local electoral commission is somewhat mitigated by a provision of the LLE which directs towards analogous application of acts of the REC.

Finally, the LEMP itself limits regulation of the procedure for electoral rights protection to the legislative realm and actually envisages that this is done by that law alone (A. 94), so it would naturally follow that it also contains a provision on analogous application of a certain procedural law. Moreover, in the case law of the Administrative Court one can find decisions in which analogous application of other laws (not LGAP) was rejected because the electoral law „did not envisage analogous application of other laws, besides the Law on Administrative Disputes". ${ }^{22}$

In regulating the complaint procedure before the electoral commission, the LEMP explicitly lists the persons who have standing (A. 94); names the remedy initiating the procedure (A. 95, para. 1) - complaint (prigovor, in contrast to zahtev - request in LGAP); lists grounds for complaint, which the LGAP as a general procedural law does not do, but leaves it to special laws (A. 95. para. 2); determines jurisdiction as to the substance of the matter to the electoral commission (A. 95 рага. 3); envisages short deadlines for submitting complaints (A. 95. рага. 4) and deciding (A. 96) by which it derogates from provisions of LGAP on deadlines for deciding (LGAP, A. 145) and envisages an exception from the general rule of a supposed negative act in case of administrative silence (LEMP, A. 96, para. 3).

Departures from LAD in the procedure before the Administrative Court are reflected in the different name of the remedy (appeal instead of the usual claim), shorter deadlines for its submission, for the response of the electoral commission and decision of the Court, exclusion of irregular legal remedies

22 E.g. Ruling AC II-4 Už. 2/20, 23 January 2020. In this case, the appellant called upon analogous application of rules on calculating deadlines in case of public holidays. 
envisaged by $L A D,{ }^{23}$ as well as a more concrete regulation of consequences of the Court's decision in full jurisdiction. As already said, the analogous application of LAD is expressly envisaged (LEMP, A. 97).

On all other aspects of the complaint and appeal procedures, provisions of LGAP and LAD could apply - and that relates to initiating procedure, determination of facts, i.e. the evidential process and deciding. Voluminous case law on that is available, both of the Administrative Court and the courts which were competent in electoral disputes in the past. However, it should be borne in mind that analogous application does not occur automatically and this fact necessitates analysis of relevant case law.

For instance, until 2012 the dominant legal position of the case law was that analogous application of LGAP does not apply to the whole election procedure, but only to the complaint procedure, so there is no place to apply the principle of officiality of the LGAP (see e.g. Vučetić, 2015a, pp. 152-153). However, in 2012 this position was partially revised, allowing the electoral commission to ex officio correct technical errors (for harsh criticism of such an opinion see Pljakić, 2012). In its opinio iuris adopted in 2016, the Administrative Court determined that there is no analogous application of LGAP's provisions on irregular legal remedies. ${ }^{24}$

On the other hand, the Administrative Court allows application of LGAP's provisions on the manner of determination of facts (now A. 102) and obligation of the competent authority to obtain data from official records (A. 103). By correctly applying LGAP, the electoral commission can, when in doubt, obtain data ex officio or oblige the complainant to provide the necessary evidence. ${ }^{25}$

\subsection{Determination of facts before the electoral commission}

Deciding electoral disputes is influenced by the specificity of electoral matters, as well as the character of electoral commissions as collegial bodies.

However, it suffices to say that proceedings before them are primarily governed by law (which is expressly stated in A. 28 LEMP). In concreto, these are

23 In case law, this provision was reasoned by calling upon "urgency and legal nature" of the procedure (Judgement of the Supreme Court of Serbia, Už. 78/02, 18 September 2002).

24 Legal position of the Administrative Court (Pravni stav Upravnog suda - in Serbian only) determined in the $58^{\text {th }}$ session of all judges on 2 February 2016. Also in Judgement of AC, Už. 41/17, 27 April 2017.

25 Judgement of AC, III-27 Už. 29/16, 17 March 2016. In this case, the electoral commission claimed that it was not possible to determine the identity of the complainant. In the already described situation, also relating to determination of complainants' identity, BEC dismissed 15 complaints of CRTA monitors for lack of standing, even though their capacity as voters could have been ascertained either by insight into official records or by demanding them to supplement their complaints, in accordance with A. 59 LGAP on editing submissions. After appeals, the Administrative Court annulled 14 of those 15 rulings (e.g. Judgement AC, 4 Už. 41/18, 9 March 2018), but only after they were supplemented by statements of appellants that they are appealing in the capacity of voters (while one was dismissed for lack of standing, Judgement AC, 16 Už. 44/18, 8 March 2018). In the repeated proceedings before BEC, 12 complaints were rejected and two dismissed. 
the rules of general administrative procedure on deliberation by collegial bodies (LGAP, A. 137), which is undisputed in case law. ${ }^{26}$

Our attention here is primarily directed towards the manner in which the electoral commission determines the facts of a case and decides on the basis thereof. Provisions of Part III of LGAP (A. 102-135) are eligible for analogous application related to that. LGAP's principle of truth and free assessment of proof (A. 10) is of particular importance here, since it demands the competent body to properly, truthfully and completely determine all the facts and circumstances relevant for a lawful decision in an (administrative) case. Thereby, the competent official (in this case, the electoral commission) decides according to its belief which facts are to be taken as proven, based on a conscientious and careful assessment of each piece of evidence separately and all evidence taken together, as well as the results of the entire procedure [emphasis added]. When the official places more trust in some evidence, and none in some other, such an assessment would have to be reasoned (Tomić, 2017, p. 129). By exception, some evidence is considered more credible than others, such as public documents determined by law, for which the presumption of accuracy applies (Ibid, pp. 129-130).

One could argue that, for reasons of urgency, and due to the need to react to a very large number of complaints in a very limited time, in electoral matters there is no place, nor need to conduct oral hearings (even though some international standards point towards the necessity of hearings, especially in case of judicial protection). ${ }^{27}$ On the other hand, the same reasons cannot justify nonapplication of other LGAP's provisions offering a range of means of evidence (A. 116-135). Case law, however, shows that only a limited number of these means are used in electoral matters and that in procedures on complaints (and later on appeals) evidence submitted by complainants is often ignored. ${ }^{28}$

Except in the case of generally known facts, the LGAP obliges the party (in this case the complainant) to propose or, if possible, submit evidence for its allegations (A. 102, para. 2). All the more so, there is an obligation of the competent official to declare itself regarding this evidence. It was already said that in the opinion of the Administrative Court, in the procedure before election commissions there is room to apply these provisions of the LGAP, but also those obliging the official to obtain data from official records (now A. 103 LGAP).

Therefore, even in case of collegial bodies, it is not enough to secure a majority for a decision of a certain content (i.e. adopting or rejecting a complaint) - even then, the competent body is obliged to conduct an appropriate eviden-

26 E.g. Judgement of the Supreme Court of Serbia, Už. 67/00, 13 December 2000.

27 See further on in this section.

28 Recommendations for improving the electoral process by organisations monitoring elections, inter alia, relate to the need to change the practice of electoral commissions and the Administrative Court in the sense that they should "besides insight into minutes of the polling boards [...] look into possibilities to obtain other evidence (statements of members of polling boards, accredited monitors and, when necessary, official representatives of other institutions)" (CRTA, 2019). 
tiary procedure and to provide a reasoning based on legal arguments. This is exactly what the July 2020 judgments of the Administrative Court say. ${ }^{29}$

In these cases the complainant claimed that by gaining insight in the bags containing electoral material he determined that the number of ballots in the bags from a large number of electoral posts (and for every post a separate complaint was submitted) for one of the candidate lists is higher than the number stated in the minutes from those posts, while the opposite happened to data for another candidate (a lower number of circled ballots in comparison to the minutes), as well as that there is disagreement in the number of used ballots and the total number of ballots. REC reasoned its rejection of all these complaints simply by the fact that more of its members voted against their adoption (calling upon its rules of procedure). The Administrative Court found this to be a significant breach of procedure (namely A. 102 LGAP on the duty of the competent authority to determine facts and circumstances relevant to case and A. 141 obliging the authority to reason its decisions). The Court found that the reasoning given "does not constitute a legally acceptable reasoning [...] since it does not contain decisive reasons as to the legal basis for the authority's assessment that the complaint is ill-founded, nor an assertation of the established facts on which the decision is based."

However, the Administrative Court stopped at the mere annulment of REC's rulings and did not examine the allegations of the appellant and the proposed evidence, i.e. it did not decide in full jurisdiction. In the repeated procedure, REC rejected all the complaints, basing its new decisions on the minutes of the polling boards - exactly the ones whose incorrectness the complainant pointed toward. ${ }^{30}$

Although the starting assumption is that electoral commissions can use any of the means of evidence provided in the LGAP, in practice the minutes of the polling boards remain dominant. The content of the minutes is determined by the law and by acts of the electoral commission, but such preference to any other type of evidence has no basis in provisions of the LEMP or the LGAP. Even if the minutes had the force of a public document (which they do not have, as that is not prescribed by any law), their credibility should be subject to challenge.

For instance, during the 2018 Belgrade local elections almost $30 \%$ of all complaints submitted ${ }^{31}$ related to suspicions of keeping parallel voter records, in most cases by members of polling boards, by entering personal data of those who came out to vote (ID numbers or numbers in the excerpts from the electoral roll). Such actions have previously been recognized in case law of the

29 E.g. Judgment AC, 20 Už. 2758/20, 4 July 2020.

It should be borne in mind that the Administrative Court delivered a great number of identical judgements, since the appeals addressed to it were in identical text and related to identical rulings of REC. All REC's rulings are available in Serbian at https://www.rik.parlament.gov.rs/ tekst/sr/2171/resenja-po-prigovorima.php, accessed 24 October 2020.

30 For an example of dismissal see Judgement AC, 24 Už. 4603/20, 19 July 2020 and for rejections see Judgement AC, 12 Už. 4807/20, 23 July 2020.

31 The author analysed 59 of such complaints, out of total 197 which were submitted according to BEC's data. 
Administrative Court as "violations of order at the polling station". ${ }^{32}$ The Belgrade Electoral Commission (BEC) rejected all these objections and 16 rulings on rejection were appealed to the Administrative Court, which also rejected the appeals. In all cases, BEC's reasoning was based solely on minutes of the polling board, and the evidence proposed by the complainants was not considered. Although several complaints proposed examination of witnesses (observers or members of the polling board), and two included material evidence (photographs and videos which were also publicly available on YouTube), the reasoning was either that such an objection was not recorded by the minutes of the polling board or that such an objection exists, but that this is "not an irregularity that affects the course of voting and determination of results." Although the same evidence was attached to appeals, the Administrative Court gave full confidence to BEC's reasoning, mostly without referring to appellants allegations. ${ }^{33}$

Such judgements are not entirely in accordance with the Court's earlier case law by which if minutes of the polling board are signed by all board members without any objections, the complainant claiming otherwise has to provide evidence which "prove certain the existence of irregularities that occurred during the voting at that polling station". ${ }^{34}$

There are examples in which the Administrative Court pointed out to electoral commissions the need to clearly state the established facts in their decisions (e.g. by accurately listing the reviewed election documentation, when complaints indicate an excess of ballots in the ballot box or the absence of certificates of voting outside of the polling station).$^{35}$

The issue of the range of permitted means of evidence, as well as the issue of potentially stronger probative force provided by election laws to minutes of polling boards, has been analysed by international election observation organizations (OSCE/ODIHR, 2013, pp. 72-73). Such restrictions are possible and can be justified, but it should be noted that Serbian legislation does not contain such restrictions, but that they have arisen in practice with no clear justification. In that sense, one should also keep in mind the practice of the ECtHR, which, referring to the Code of Good Practice in Electoral Matters, warns of excessive formalism in procedures for protection of the right to vote. Electoral commissions and courts, when considering appeals, should make a genuine effort to examine the appellant's allegations, and their decisions must be adequately reasoned. In this way, they show a "genuine concern" for the protection of the right to vote (ECtHR, 18705/06, paras. 86, 90). Election irregularities are very often recorded by accredited observer organizations, and their role in the evidentiary process has been recognized in relevant inter-

32 Judgment AC, III-7 Už. 34/17, 11 April 2017.

33 E. g. Judgement AC, 23 Už. 38/18, 8 March 2018; Judgement AC, 2 Už. 58/18, 9 March 2018; Judgement AC, 25 Už. 106/18, 10 March 2018.

34 E. g. Judgement AC, 4 Už. 3/18, 11 January 2018.

35 E. g. Judgment AC, 18 Už. 311/16, 4 May 2016; Judgment AC, 22 Už. 350/16, 6 May 2016 (also analysed in Vučetić, 2020, pp. 109-110). 
national documents (Venice Commission CDL-AD (2002) 23), as well as in the practice of the ECtHR (Suksi, 2016).

The right to submit evidence is considered an integral part of effective protection of the right to vote. Moreover, if the complainant does not have access to suitable evidence, the securing of such evidence should be an obligation of the electoral administration. The burden of proof - on the side of the complainant or ex officio on the side of the bodies in charge of conducting elections - should be regulated by law (Venice Commission CDL-EL, (2019)001, p. 25).

\subsection{The Administrative Court's review}

Contribution of the Administrative Court to building case law in respect of electoral rights protection in general is undoubtable, as well as in respect of analogous application of LGAP, which was already elaborated here (also Vučetić, 2020, pp. 98-99). However, regardless of the explicit legal basis for analogous application of LAD in electoral disputes before the Administrative Court, it can be said that the case law analysed thus far mostly shows the Court's deference to argumentation and assessment of evidence by the electoral commission - if not in the first appeals, then in the cases of repeated appeals filed with it.

Deficiencies of Serbian legislation to that end have been earlier ascertained in reports of international organisations (Venice Commission, CDL-AD, (2006)013). This particularly relates to absence of a public hearing before the Court $^{36}$ and the non-existence of an express legal guarantee of a fair, public and transparent hearing in that phase of the procedure. Moreover, even if a public hearing would in theory be applicable through analogous application of LAD, the Administrative Court expressly excludes this option "having in mind the nature of electoral disputes". ${ }^{37}$ This case law has already been criticized by Serbian authors, particularly in cases of serious claims of vote buying (Nastić, 2016, pp. 173-174).

By excluding a public hearing, the Administrative Court practically also excluded the possibility for presentation of evidence before it, or for supplementing the evidential process conducted before the electoral administration, which is otherwise possible according to LAD (LAD, A. 33; Tomić, 2010, pp. 475-480).

The Court still rarely employs the possibility to decide in full jurisdiction (Cucić, 2016, p. 19), even though there are authors who claim that this occurs in a significant number of cases in electoral disputes (Ivanović, 2013). Such claims are, nevertheless, still a matter of general impression, since there is no comprehensive analysis on that issue. What would probably be correct to say is that the Court does decide in full jurisdiction more often in electoral, than in other matters in its competence. Such examples have already been recognised in literature (e.g. Nastić, 2016, pp. 172-173; Vučetić, 2014, pp. 1290-1291; Vučetić, 2015b, p. 142; Vučetić, 2020, pp. 98-99). However, it can

36 In time of these reports, before the Serbian Supreme Court.

37 E.g. Judgement AC, 20 Už. 2758/20, 4 July 2020. 
also be noted that appellants in electoral disputes regularly ask the Court to decide in full jurisdiction, but the Court does not do so in most cases. Judgements of the Court in full jurisdiction related to different issues - from rejection to proclaim an electoral list to ordering repeat voting. By deciding in full jurisdiction, the Administrative Court also adopted some important legal positions in electoral matters. ${ }^{38}$

As in case of analogous application of LGAP, the Administrative Court has a grounded position on the application of LAD in electoral disputes. Besides exclusion of public hearing, there is also no place for application of LAD's rules on silence of the administration; ${ }^{39}$ on the interested persons ${ }^{40}$ or analogous application on the law on civil procedure. ${ }^{41}$ The Court's reasoning of the last decision is interesting in the sense that it held that it is not possible to draw the conclusion on analogous application of the Law on Civil Procedure "via" LAD (the only law whose analogous application is expressly envisaged). On the other hand, the same court has repeatedly allowed analogous application of LGAP "via" rules of procedure of REC, an act of a far lesser legal force.

Also, in cases analysed here in which the Administrative Court ruled that there is no place for analogous application of certain provisions of LAD (and this also applies to previously described decisions regarding application of the LGAP), the Administrative Court does not provide a more detailed reasoning of such a position, but simply states that it is not possible or "not appropriate" or that such a position is taken having in mind the nature of electoral disputes.

\section{Discussion and conclusions}

One could argue that in procedures for electoral rights protection, especially those initiated after the election day by election candidates, complaints are submitted by the losers, and that the winners get to decide on them. This view is enabled by the fact that electoral commissions are composed of party and candidate lists representatives.

However, such a completely simplified viewpoint would ignore the fact that both the electoral process and the protection of the right to vote are regulated by the Constitution and the law, and that the bodies in charge of conducting elections should be strongly bound by them. (Non)application of appropriate procedural rules substantially affects the degree and effectiveness of legal protection of the right to vote, having in mind the standards of the Venice Commission and the ECtHR. Moreover, it undermines the trust in the electoral process and conditions under which elections are conducted, which,

38 E.g. it was determined that each registered minority party can have such a status granted (Judgement AC, II-2 Už. 88/16, 6 April 2016) or that an electoral coalition cannot consist of a political party and a citizens' group (Judgement AC, Už. 88/12, 23 April 2012).

39 E.g. Ruling AC, II-3 Už. 28/14, 28 March 2014.

40 E.g. Judgement AC, 2 Už. 34/20, 29 May 2020.

41 E.g. Ruling AC, III-3 Už. 4/14, 31 January 2014. 
inter alia, was the reason for the recent boycott of parliamentary elections by a large portion of the Serbian opposition.

Serious criticism vis-à-vis method of appointment and composition of electoral commissions have already been noted, and are, without a doubt, part of the problem of ineffective electoral rights protection. Although necessary, professionalization of electoral administration alone cannot compensate for deficiencies in procedural rules. These two sets of measures should, therefore be viewed as complementary. One should bear in mind that the Administrative Court, acting as a second instance in these procedures, does not suffer from same deficiencies in position and independence - it is a court of law, with all characteristics of an independent and impartial tribunal according to A. 6 of the ECHR.

Still, the analysis given here, mainly focused on relevant legislation and case law of both electoral bodies and courts, found a predominant use of a limited circle of evidence and that evidence provided by complainants are not equally considered and valued as the ones coming from polling boards. Even though analogous application of the LAD is explicitly provided by electoral legislation, case law of the Administrative Court shows a high level of deference to decisions and argumentation of electoral commissions, without complementing the facts already determined in prior proceedings, as well as still relatively rare or selective adjudication in full jurisdiction.

Although it is imaginable that the reasons for such an outcome come outside of the legal sphere, the solutions sought in this article are largely limited to proposals for amendment and specification of electoral legislation, at the same time recognising that changes are necessary in other aspects - primarily, selection and functioning of the electoral administration.

By only marginal application of procedural possibilities provided by rules of administrative procedure, electoral bodies and courts fail to provide, in the words of ECtHR, a "genuine effort" to examine allegations of electoral irregularities (even if they come in great numbers) and to prove they are genuinely concerned for the protection of the right to vote. It seems as if their efforts are simply focused on formally completing the procedure and not providing substantive protection. In view of constitutional guarantees (as well as ones under the ECHR) of every individual's right to vote, it is even irrelevant if these allegations if proven could have a direct influence on election results.

The Administrative Court (and before it, the Supreme Court of Serbia) did invest significant efforts during the past two decades to harmonise its case law regarding analogous application of the LGAP. However, disparities remain. Further harmonisation could be implemented on three levels: the level of legislation; level of electoral administration and level of case law.

First of all, there is a need for more detailed regulation of procedures rules for dealing with complaints - more explicit obligation of electoral commissions to apply the rules of the LGAP in establishing facts and taking of evidence, especially in cases where the complainant provides or proposes additional evi- 
dence. This can be done by defining more specific rules in the LEMP, as the main law in the electoral field, and there is also a need to harmonize various electoral laws, or even to codify the entire electoral matter. The importance of minutes of the polling boards in the process of proving election irregularities is undoubted, but their place among all possible means of evidence must be specified.

Case law of electoral commissions should be harmonized - both at the level of the commissions themselves, and with the views of case law of the Administrative Court. Moreover, in line with the principle of predictability of LGAP, any changes in established case law would have to be sufficiently reasoned.

Finally, there is still room for harmonization of case law of the Administrative Court itself, delivered in various election cycles, and this can best be done through legal positions adopted by the session of all judges of this court. 


\section{References}

Beširević, V. et al. (2017). Study on the Case-Law of the European Court of Human Rights Applicable in Administrative Disputes. Danilovgrad: Regional School of Public Administration. At <https://www.respaweb.eu/download/ doc/Study\%20on\%20the\%20Case-Law\%20of\%20the\%20ECtHR\%20Appli cable\%20in\%20Administrative\%20Disputes.pdf/a1853115daf8fc9a5127306a ae093620.pdf>, accessed 20 October 2020.

Bieber, F. (2003). The Serbian Opposition and Civil Society: Roots of the Delayed Transition in Serbia. International Journal of Politics, Culture, and Society, 17, pp. 73-90. DOI: 10.1023/A:1025388926816.

Castaldo, A. (2020). Back to Competitive Authoritarianism? Democratic Backsliding in Vučić's Serbia. Europe-Asia Studies, pp. 1-22. DOI: 10.1080/ 09668136.2020.1817860>.

CRTA (Centar za istraživanje, transparentnost i odgovornost). 2018a. Beogradski izbori 2018: finalni izveštaj CRTA posmatračke misije. At <https://crta.rs/wpcontent/uploads/2018/08/CRTA_BG-izbori-finalni-izvestaj.pdf>, accessed 1 August 2020.

CRTA. (2018b). Pravo građana na slobodne izbore i uloga izbornih organa. At <https://crta.rs/wp-content/uploads/2018/03/Finalno_05-pravo-gradjanaNOV0.pdf>, accessed 1 August 2020.

CRTA. (2019). CRTA preporuke za unapređenje izbornih uslova do 2020. godine. At <https://crta.rs/wp-content/uploads/2019/03/CRTA-2020-PREPORUKEweb.pdf>, accessed 1 August 2020.

Cucić, V. (2011). Appeals in Special Administrative Domains. Transylvanian Review of Administrative Sciences, 34e, pp. 63-79. At <https://rtsa.ro/tras/ index.php/tras/article/view/300/293>, accessed 23 October 2020.

Cucić, V. (2016). Upravni spor pune jurisdikcije: modeli i vrste. Belgrade: Pravni fakultet.

Cvejin, Ž. (2020). Elections in Serbia - Simulation of Democracy. Belgrade: CRTA. At <https://crta.rs/en/elections-in-serbia-simulation-of-democracy/>, accessed 23 October 2020.

Dimitrijević, P. (2014). Neka otvorena pitanja primene ZUP-a. Zbornik radova Pravnog fakulteta u Nišu, 68, pp. 143-156. DOI: 10.5937/zrpfni1468143D.

Danas. (2020). „Radulović: Upravni sud usvojio 175 žalbi DJB-a.” 30. 6. 2020. At <https://www.danas.rs/politika/izbori-2020/radulovic-upravni-sud-usvojio175-zalbi-djb-a/>, accessed 20 July 2020.

European Commission for Democracy through Law (Venice Commission). (2002). Code of Good Practice in Electoral Matters - Guidelines and Explanatory Report, CDL-AD (2002) 23 Or. Fr. At <https://rm.coe.int/090000168092af01>, accessed 24 October 2020.

European Commission for Democracy through Law (Venice Commission). (2019). Draft Report on Election Dispute Resolution, CDL-EL (2019)001*. At <https:// www.venice.coe.int/webforms/documents/default.aspx?pdffile=CDLEL(2019)001>, accessed 23 October 2020.

European Court of Human Rights [ECtHR]. (2019). Guide on Article 3 of Protocol No. 1 to the European Convention on Human Rights - Right to free elections. Strasbourg. At <https://www.echr.coe.int/Documents/Guide_Art_3_ Protocol_1_ENG.pdf>, accessed 1 August 2020. 
ECtHR, Namat Aliyev v. Azerbaijan, No. 18705/06, Judgment of the Court (First Section) on Merits and Just Satisfaction of 8 April 2010, ECLI:CE:ECHR: 2010:0408JUD001870506.

Fasone, C. and Piccirilli G. (2017). Towards a lus Commune on Elections in Europe? The Role of the Code of Good Practice in Electoral Matters in 'Harmonizing' Electoral Rights. Election Law Journal (16)2, pp. 247-254. DOI: 10.1089/elj.2016.0414

Ivanović, J. (2013). Spor pune jurisdikcije u upravno-sudskoj praksi Republike Srbije. At <http://www.fcjp.ba/templates/ja_avian_ii_d/images/green/Jelena _Ivanovic.pdf>, accessed 1 August 2020.

Lilić, S. (2019). Začarani krug opšteg i posebnog upravnog postupka (i kako iz njega izaći). Savremena uprava, 4/5, pp. 68-77. At <http://media.savremena uprava.rs/2020/02/DVOBROJ-4-5-R.pdf>, accessed 24 October 2020.

Lončar, Z. (2017). Ostvarivanje prava građana u posebnim upravnim postupcima. In S. Perović, ed., Aktuelna pitanja savremenog zakonodavstva. Zbornik radova sa Savetovanja pravnika, 4-8. 7. 2017. Budva. Belgrade: Savez udruženja pravnika Republike Srbije i Republike Srpske, pp. 173-190.

Lukić, R. D. (1994). Uvod u pravo. Belgrade: Službeni list SRJ.

Milenković, D. (2012). Organi nadležni za sprovođenje izbora - pojam i oblici izborne administracije (uprave) u Srbiji. In O. Nikolić and V. Đurić, eds., Izbori u domaćem i stranom pravu. Belgrade: Institut za uporedno pravo, pp. 180-207.

Ministarstvo državne uprave i lokalne samouprave [MDULS]. (2017). Utvrđena matrica za usaglašavanje posebnih zakona sa Zakonom o opštem upravnom postupku". At <http://mduls.gov.rs/obavestenja/utvrdjena-matrica-zausaglasavanje-posebnih-zakona-sa-zakonom-o-opstem-upravnom-postupku /?script=lat>, accessed 1 August 2020.

Nastić, M. (2014). Izborni sporovi - odnos Upravnog i Ustavnog suda Srbije. Sveske za javno pravo, (5), pp. 66-74.

Nastić, M. (2016). Judicial Control Over Elections. In M. Lazić and S. Knežević, eds., Legal, Social and Political Control in National, International and EU Law. Collection of papers from the International Scientific Conference held on 19-20 May 2016, Niš, Serbia. Niš: Pravni fakultet Univerziteta u Nišu.

OSCE/ODIHR. (2013). Guidelines for Reviewing a Legal Framework for Elections. At < https://www.osce.org/odihr/elections/104573>, accessed 24 October 2020.

Pajvančić, M. (2001). Zloupotreba sudstva u izborima. In J. Trkulja, ed., Kriza i reforma pravosuđa, pp. 106-114. Belgrade: Centar za unapređivanje pravnih studija.

Pavlović, D. (2020). The political economy behind the gradual demise of democratic institutions in Serbia. Southeast European and Black Sea Studies, 20(1), pp. 19-39. DOI: 10.1080/14683857.2019.1672929.

Petit, D. (2000). Resolving Election Disputes in the OSCE Area: Towards a Standard Election Dispute Monitoring System. Warsaw: OSCE/ODIHR. At <https://www.osce.org/files/f/documents/b/b/17567.pdf>, accessed 1 August 2020.

Pljakić, Lj. (2012). Izborna volja građana u izbornom postupku se štiti prigovorima i žalbama a ne po službenoj dužnosti. Izbor sudske prakse, (9), pp. 22-24. 
Pljakić, Lj. (2016). Upravno postupanje u novom Zakonu o opštem upravnom postupku. Pravni život, (10), pp. 237-249.

Popova, M. (2006). Watchdogs or attack dogs? The role of the Russian courts and the central election commission in the resolution of electoral disputes. Europe-Asia Studies, (58)3, pp. 391-414. DOI: 10.1080/09668130600601800.

Popović, D., Marinković, T. and Radojević, M. (eds). (2017). Komentar Konvencije za zaštitu ljudskih prava i osnovnih sloboda. Belgrade: Službeni glasnik.

Regulatorni institut za obnovljivu energiju i životnu sredinu [RERI]. (2019). „Radovi na Kalemegdanu naneli bi štetu javnom interesu - Upravni sud naložio odlaganje radova na izgradnji gondole na Kalemegdanu", At <https://www.reri.org.rs/radovi-na-kalemegdanu-naneli-bi-stetu-javnominteresu-upravni-sud-nalozio-odlaganje-radova-na-izgradnji-gondole-nakalemegdanu/>, accessed 1 August 2020.

Stojanović, D. (2012). Izborni sporovi u nadležnosti ustavnih sudova. In O. Nikolić and V. Đurić, eds., Izbori u domaćem i stranom pravu. Belgrade: Institut za uporedno pravo, pp. 26-50.

Suksi, M. (2016). The Use of Election Observation Reports in Regional Human Rights Jurisprudence. Nordic Journal of Human Rights, (34)4, pp. 229-246.

Spasojević, Ž. (1991). Analogija i tumačenje (izbor). In D. Basta, ed., Preobražaji ideje prava. Belgrade: Pravni fakultet, pp. 113-129.

Thompson, M. and Kuntz P. (2004). Stolen Elections: The Case of the Serbian October. Journal of Democracy, (15)4, pp. 159-172.

Tomić, Z. (2010). Komentar Zakona o upravnim sporovima, sa sudskom praksom. Belgrade: Službeni glasnik.

Tomić, Z. (2017). Komentar Zakona o opštem upravnom postupku, sa sudskom praksom i registrom pojmova. Belgrade: Službeni glasnik.

Upravni sud. (2019). Godišnji izveštaj o radu Upravnog suda po materijama za period od 01. januara 2018. godine do 31. decembra 2018. godine. At <http://www.up.sud.rs/uploads/useruploads/Izvestaji-o-radu-suda/GODIŠNJIIZVEŠTAJA-ZA-2018.pdf>, accessed 1 August 2020.

Vasić, R., Jovanović, M. and Dajović, G. (2019). Uvod u pravo. Belgrade: Pravni fakultet.

Venice Commission \& OSCE/ODIHR, CDL-AD (2006). Joint Recommendations on the Laws on Parliamentary, Presidential and Local Elections, and Electoral Administration in the Republic of Serbia. Adopted by the Venice Commission at its 66th Plenary Session, on 17-18 March 2006. At <https://www.venice. coe.int/webforms/documents/?pdf=CDL-AD(2006)013-e>, accessed 24 October 2020.

Vučetić, D., Janićijević D. and Ranđelović N. (2014). Administrative-Judicial Protection of Electoral Right. Teme (3), pp. 1273-1294. At <http://teme2. junis.ni.ac.rs/public/journals/1/previousissues/teme3-2014/teme\%203-201417.pdf>, accessed 24 October 2020.

Vučetić, D. (2015a). What Needs To Be Changed In Serbian Legal Regime On Electoral Rights Protection? Facta Universitatis - Series: Law and Politics, (13)2, pp. 149-160. At <http://casopisi.junis.ni.ac.rs/index.php/FULawPol/ article/view/1485/890>, accessed 24 October 2020.

Vučetić, D. (2015b). Postupak zaštite izbornog prava na lokalnim izborima u Republici Srbiji. In P. Dimitrijević, ed., Zaštita ljudskih i manjinskih prava u 


\section{Jelena Jerinić}

evropskom pravnom prostoru - knjiga peta. Niš: Pravni fakultet Univerziteta u Nišu, pp. 131-146.

Vučetić, D. (2020). Analiza upravno-sudske zaštite izbornog prava pružene povodom lokalnih izbora 2016. godine. In G. Obradović, ed., Projekat „Usklađivanje prava Srbije sa pravom EU”, zbornik radova - knjiga sedma. Niš: Pravni fakultet Univerziteta u Nišu, pp. 93-118. 